Ann. Biol. anim. Bioch. Biophys. I966, 6 (4), 467-478.

\title{
GALACTOKINETIC RESPONSES TO OXYTOCIN IN THE EWE
}

\author{
M. MORAG (1) and S. FOX \\ Depariment of Agriculture, University of Reading, England
}

SOMMAIRE

Un groupe de 15 brebis de différentes races anglaises (voir tabl. 2) est utilisé pour juger de l'efficacité de l'ocytocine pour l'éjection du lait résiduel. La traite est effectuée à la machine dans des conditions rigoureusement standard et par les mêmes personnes pendant toute l'expérience. Après la traite les doses d'ocytocine alternativement utilisées sont au nombre de quatre $(2,5-5-$ 7,5 - Io UI) un témoin reçoit du sérum physiologique. Les quantités de lait restant dans la glande après cette première injection sont évaluées par deux injections successives de 5 UI.

Les injections sont faites par le moyen d'un cathétère posé à demeure dans la veine jugulaire.

Le schéma expérimental est décrit sur le tableau I. Nous voyons la description des 4 traitements à l'ocytocine plus a témoin $(\mathrm{A}, \mathrm{B}, \mathrm{C}, \mathrm{D}, \mathrm{E})$ répartis en carré latin sur 5 périodes consécutives de deux jours chacune, au cours du $4^{\mathrm{e}}$ mois de la lactation des animaux.

Chaque période dure deux jours et comporte les intervalles suivant entre chaque traite :

$$
\text { I } 2 \mathrm{~h}-4 \mathrm{~h}-8 \mathrm{~h}-\mathrm{I} 2 \mathrm{~h}-8 \mathrm{~h}-4 \mathrm{~h}-\mathrm{I} 2 \mathrm{~h}
$$

Les résultats du tableau 3 montrent : résiduel ;

$\mathrm{I}^{\circ}$ il faut au moins deux injections successives d'ocytocine pour obtenir $96-97 \mathrm{p}$. $100 \mathrm{du}$ lait

$2^{\mathrm{o}}$ une faible éjection est obtenue avec le sérum physiologique;

$3^{o}$ l'élimination régulière du lait résiduel par l'ocytocine a un effet galactopoḯtique puissant et un effet inhibiteur sur l'éjection normale ;

$4^{\circ}$ le taux de sécrétion n'est pas affecté par l'intervalle de traite ni par l'intervalle précédant ce dernier, tout au moins dans les limites de l'expérience.

\section{INTRODUCTION}

Since the first demonstration of the galactokinetic properties of posterior pituitary extract by OTT and SCOTT (IgIo), oxytocin has been widely used for the removal of residual milk (see review by ELLIOTT, I959), but little critical dose-reponse assess-

(1) Adresse actuelle : Negrev Institute for Arid Zone Research Beersheva, Israel. 
ment has been carried out in the work on farm animals. Most early workers sought only to measure residual milk and used single large doses of crude posterior pituitary extract or of Pitocin. These studies involved isolated or periodic removals of residual milk. The first report of continuous removal of residual milk with the aid of oxytocin at every milking was by KOSHI and PETERSEN (I955). Before embarking on their experiments they carried out empirical dose-response trials. They reported that intra-muscular, intra-vaginal and subcutaneous routes of administration were ineffective. When, however, I i.u. was injected intravenously, it yielded 80 per cent of the milk that was obtained from 5 i.u. ; Io i.u. tended to give more than 5 i.u., but 20 i.u. gave a similar response to Io i.u. On the basis of this somewhat uncritical assessment most workers have used a ro i.u. dose for residual milk studies in cows. ELLIOTT (I959) questioned the efficiency of this dose for complete removal of residual milk. Extrapolation of cumulative curves for milk and fat against time (based on measurements in which residual milk was removed) crossed the $x$ axis well above the point of origin. Only when EILIIOTT used two separate doses of Io i.u., each administered painlessly through a semi-permanent venous cannula, did she obtain curves which appeared to pass through the point of origin.

Working with Merino ewes, McCANCE (I959) tested a dose range from 0.25-10 i.u. injected intravenously before milking. There was a slight tendency for more efficient removal as the dose increased. Dose efficiency was expressed in terms of the amount of milk ejected by a second standard (5 i.u.) injection. No statistical analysis is given. Denamur and Martine'T (I96I) described a linear relationship between the percentage of residual milk and the logarithm of the oxytocin dose. Whilst the dose ranged from 0.I-5 i.u., the response ranged only from 9.7-I4.2 p. Ioo of total milk. Their assay was carried out with a Latin square design using 16 ewes. The treatments were applied every fourth day to avoid carry-over effects and were repeated four weeks later. This is the first trial with a satisfactory design. FyaL (I96I) carried out dose-response trials on Awassi ewes, and recommended the use of two injections (ro i.u. followed by 5 i.u.) to ensure satisfactory removal of residual milk. SEMJAN (I964) working with catheterised teats on Improved Moravian ewes was satisfied that Io i.u. of oxytocin administered subcutaneously in the thigh, accompanied by strong udder massage, assured complete removal of residual milk. We can confirm Semjan's assumption, as we have fitted regression lines to data that he obtained using this route and this dose (SFMJAN, I962), and extrapolation (as in ELI, IOTT, r959) indicates that the udder contained a small negative quantity of milk and fat at o hours.

\section{PREI,IMINARY OBSERVATIONS}

We have carried out preliminary observations on the route of oxytocin administration in Half-bred and Dorset Horn ewes. Using a dose range of $0.5-40$ i.u., of Syntocinon, intra-muscular and sub-cutaneous injections, as well as nasal spray (see review by INGERSLEV and PINHOLT, I962), were investigated and their effectiveness in removal of residual milk was estimated against a following control intra- 
venous injection of Io i.u. None of the above routes was able to produce a consistent, reliable or complete ejection. The time-lag from the administration of the oxytocin until the milk appeared in the collecting jar (if it appeared at all) varied from $3 \mathrm{I} / 2$ to 15 minutes. On the other hand intravenous administration gave immediate and satisfactory results. Using this route the mean time from administration until the appearance of milk in the jars was 29 seconds (range $15-45$ seconds). This latter measurement was carried out on 18 ewes at 6 consecutive milkings. The within-ewe variation was large and it would, therefore, appear that the time-lag is not an individual characteristic of a particular ewe.

These initial trials were followed by a study on 20 ewes (Io Dorset Horns and Io Half-breds), in which five doses from 0.25 i.u. to Io i.u. and a control saline injection were tested. Each dose was followed by a second injection of either 5 i.u. or Io i.u. The trial was carried out with the two breeds in two Io $\times$ Io Latin squares balanced for the estimation of residual effect (WILLAams, 1949). Treatments were applied every third day at a.m. milking (after a 16 hour night interval). The oxytocin was administered through semi-permanent polythene cannulae inserted in the jugular vein. Illness of $I_{5}$ of the ewes prevented the completion of the trial and the full analysis of the results. Inspection of salvaged means indicated that residual milk was satisfactorily removed by two injections of 5 i.u. each. There appeared to be no differences in galactokinetic response between the breeds.

It is concluded that the quantitative range of galactokinetic response to oxytocin has not yet been adequately described in domestic animals. The investigation of the minimal effective dose necessary for complete udder evacuation is particularly important in view of the galactopoeitic role of oxytocin suggested by BENSON and FOLLEY (I956) and clearly demonstrated by JeNAMur (I953) and by Denamur and Martinet (I96I). It is no less important because so many experimental designs have been based on the oxytocin removal of residual milk. The following experiment was, therefore, initiated in order to examine the dose response to oxytocin in terms of ejection of residual milk in ewes, and to determine if there is any interaction between the galactokinetic properties of exogenous oxytocin and interval length (and/or amount of residual milk).

\section{MATERIALS AND METHODS}

The experiment was carried out using a $5 \times 5$ Latin square split-plot design (table I). The main plot treatments were oxytocin levels and the sub-plots were different milking interval lengths. Each treatment injection was followed by two standard control injections of 5 i.u. each. Each period lasted two days and included six milking intervals (see table $\mathbf{r}$ ), giving a total duration for the experiment of io days. The sub-plot design provided two estimates of each of the 4,8 and I 2 hour intervals, so that every interval had each of the other sub-plots as preceding intervals (see table r).

Milking was carried out in a herring-bone parlour using four Alfa-Laval units (I 80 pulsations a minute with a ratio of $\mathrm{I}: \mathrm{I}$ at a vacuum level of $33 \mathrm{~cm} \mathrm{Hg}$ ). The ewes were milked by machine and then hand stripped, the sum being the yield of Commercial Milk (C.M.). The first injection was. then given and the ewes again machine milked and hand stripped, giving Residual Milk I (R.M.I) The second and third injections were given and each was followed by hand milking, giving R.M. 2 and R.M. 3 , respectively. The ewes were always milked in the same order and the inaccuracy of any interval length was never more than 2 minutes. All milkings and injections were carried out by the same two operators. The ewes were neither prewashed nor stimulated before the application of the teatcups. All milkings, hand and machine, were accompanied by vigorous udder massage.

Annales de Biologie animale. - 1966. 
In the abortive experiment of 1963 (described above) a similar dose range of oxytocin had been examined. The use of two injections only, and of two levels of control injection, necessitated the large $10 \times$ ro Latin square. The introduction of a second control injection (Injection III) yielded comparable data using a smaller square. Moreover, the combination of three injections yielded further information than was possible with only two. Complete udder evacuation on the control treatment was more certain than in the previous design.

TABLE I

Experimental design

\begin{tabular}{lll|l|l|l|l|l|l}
\hline \hline & & & & & & & & \\
\hline
\end{tabular}

* Data discarded from these ewes (see table II).

Main plots

(Oxytocin levels)

\begin{tabular}{|c|c|c|c|}
\hline \multirow{2}{*}{$\begin{array}{l}\text { Oxytocin } \\
\text { treatments }\end{array}$} & \multicolumn{3}{|c|}{ Injections } \\
\hline & $\begin{array}{c}\text { I } \\
\text { (i.u.) }\end{array}$ & $\underset{\text { (i.u.) }}{\text { II }}$ & $\begin{array}{l}\text { III } \\
\text { (i.u.) }\end{array}$ \\
\hline A & 7.5 & 5 & 5 \\
\hline B & 5.0 & 5 & 5 \\
\hline $\mathrm{C}$ & $0^{*}$ & 5 & 5 \\
\hline D & 2.5 & 5 & 5 \\
\hline $\mathrm{E}$ & 10.0 & 5 & 5 \\
\hline
\end{tabular}

* Consisted of $2 \mathrm{ml}$. of physiological saline.

\section{Sub-plots}

(Milking intervals)

\begin{tabular}{l|l|l|l|l} 
Milking times & Day I & $0800 \mathrm{hrs}$ & $1200 \mathrm{hrs}$ & $2000 \mathrm{hrs}$ \\
Day II & $0800 \mathrm{hrs}$ & $1600 \mathrm{hrs}$ & $2000 \mathrm{hrs}$ \\
\hline
\end{tabular}

Details of the experimental ewes are given in table 2 . 'Twenty ewes, all at the end of the third month of lactation, were ranged according to their milk yield over the previous ro days and blocked into four yield groups (for details see table 2). Allocation to treatment was by randomisation. Intra-venous nylon cannulae were inserted in the left jugular of all ewes three days prior to the start of the experiment. Two types of cannulae were used. In the three highest yielding groups 
a heavier tube (Portex Red-ext. diam. I.65 mm) (1) was used, whilst in the lowest group a thinner (Portex White-ext. diam. I.34 mm) was tried. The latter was more difficult to insert because of a tendency to kink. The cannulae were permanently closed and injection was through a piercible rubber cap. ( $\left.{ }^{2}\right)$ The ewes' blood was effectively anti-coagulated by the intra-venous administration of $700 \mu \mathrm{g}$ of Malayan viper - Ancistrodon rhodostoma (BOIE) - venom, given every third day.

The ewes were accustomed to the presence of the experimenter and to handling of their necks during the week (I4 milkings) prior to the experiment. The animals appeared quite oblivious to the activities around their heads and would continue eating the concentrates. They showed no discernible response either to the handling or, indeed, to the actual introduction of the injected solution into the blood stream.

TABLE 2

Details of experimental animals

\begin{tabular}{|c|c|c|c|c|c|}
\hline Number & Breed* & $\begin{array}{l}\text { Age } \\
\text { in } \\
\text { years }\end{array}$ & $\begin{array}{c}\text { Days after } \\
\text { lambing }\end{array}$ & $\begin{array}{l}\text { Mean daily yield } \\
\text { over } 10 \text { days prior } \\
\text { to experiment in } \mathrm{ml}\end{array}$ & Comments \\
\hline \multicolumn{6}{|c|}{ High yield group } \\
\hline $\begin{array}{l}1 \\
2 \\
3 \\
4 \\
5\end{array}$ & $\begin{array}{l}\text { P.D. } \\
\text { D.H. } \\
\text { … } \\
\text { C.B. . . . . } \\
\text { C. } \\
\text { D.C.B. }\end{array}$ & $\mid \begin{array}{c}2 \frac{1}{2} \\
4 \frac{1}{2} \\
\ldots .7 \\
5 \\
3\end{array}$ & $\begin{aligned} & 95 \\
& 81 \\
& \\
& 88 \ldots \ldots \\
& 88 \\
& 87\end{aligned}$ & $\begin{array}{c}1.242 \\
1.190 \\
1.060 \ldots \ldots \ldots \\
1.266 \\
1.076\end{array}$ & acute mastitis \\
\hline \multicolumn{6}{|c|}{ High medium yield group } \\
\hline $\begin{array}{l}11 \\
12 \\
13 \\
14 \\
15\end{array}$ & $\begin{array}{l}\text { D.C.B. } \\
\text { D.H. } \\
\text { ‥B. } \cdots \cdots \\
\text { D.C.B. } \\
\text { C.B. }\end{array}$ & $\begin{array}{c}3 \\
6 \\
\cdots \\
2 \ldots \\
2 \frac{1}{2} \\
6\end{array}$ & $\begin{array}{r}89 \\
89 \\
88 \ldots \ldots \\
88 \\
86\end{array}$ & $\begin{array}{c}949 \\
1.043 \\
\ldots \ldots \ldots .949 \ldots \ldots \ldots \\
956 \\
1.019\end{array}$ & fatal pneumonia \\
\hline \multicolumn{6}{|c|}{ Low medium yield group } \\
\hline $\begin{array}{l}21 \\
22 \\
23 \\
21 \\
25\end{array}$ & $\begin{array}{c}\text { P.D. } \\
\text { P.D. } \\
\text { P.C.B. } \\
\text { H.B. } \\
\text { C.B. }\end{array}$ & $\begin{array}{l}2 \\
2 \frac{1}{2} \\
2 \frac{1}{2} \\
7 \\
3\end{array}$ & $\begin{aligned} & 89 \\
& 93 \\
& \ldots \ldots 88 \ldots \ldots \\
& 88 \\
& 82\end{aligned}$ & $\begin{array}{r}910 \\
819 \\
871 \\
891 \\
826\end{array}$ & severe scours \\
\hline \multicolumn{6}{|c|}{ Low yield group } \\
\hline $\begin{array}{l}31 \ldots \\
32 \\
33 \\
34 \ldots \\
35\end{array}$ & \begin{tabular}{|c}
$\ldots \ldots$ D.C.B. $\ldots \ldots$ \\
H.B. \\
D.C.B. \\
… \\
$\quad$ H.B. \\
D.C.B.
\end{tabular} & 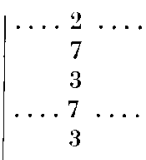 & $\begin{array}{r}\ldots .8 \\
89 \\
89 \\
86 \\
\ldots \ldots . \\
84 \ldots \ldots \\
84\end{array}$ & $\mid \begin{array}{rrr}\ldots \ldots \ldots & 520 & \ldots \ldots \\
& 614 & \\
& 741 & \\
\ldots \ldots \ldots & 764 & \ldots \ldots \\
637 & \end{array}$ & cannula blocked \\
\hline
\end{tabular}

* P.D. Polled Dorset Horn

D. H. Dorset Horn

H.B. Half-bred (Border Leicester $\times$ Cheviot)

C.B. Cross-bred (Dorset Horn $\times$ Half-bred)

D.C.B. Dorset Cross-bred (Dorset Horn $\times$ Cross-bred)

** Cannulated with the thinner (white) tube.

(1) Manufactured by Portland Plastics, Ltd.

(2) Caps were kindly supplied by Mr W. F. Ticehurst of Armour Pharmaceutical Co. Ltd. 
Treatment means

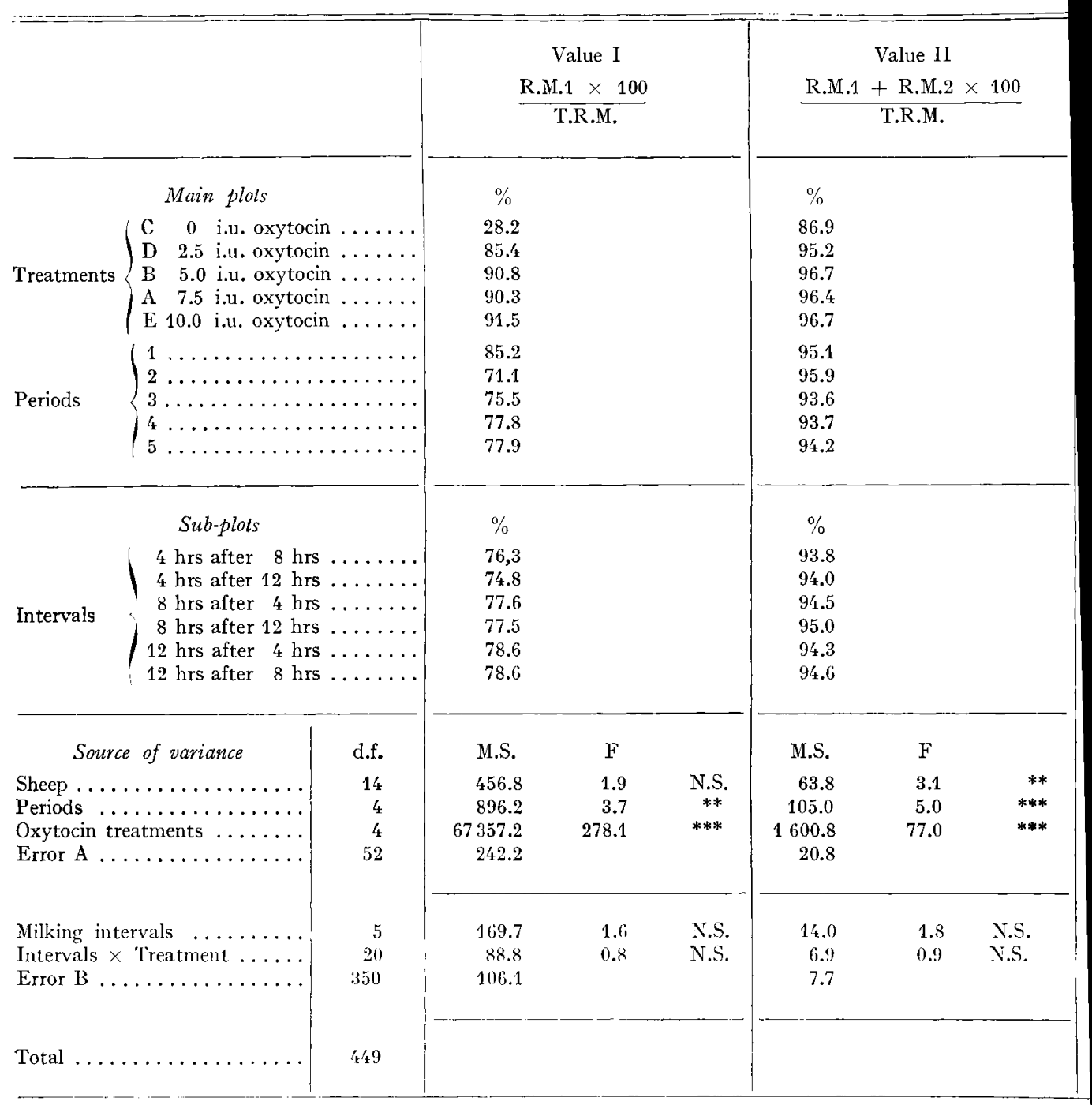

(1) Value I. - Calculated by adding the machine milking and hand stripping in response to injection I and expres Value II. - Calculated as the total of the milk obtained as a response to injection I and II as a percentag Value III. - Calculated as the total milk at any milking session.

Value IV. - Calculated as the sum of machine milking and stripping prior to injection.

Value V. - Calculated as the sum of all milk given in response to Injections I, II, and III.

N.S. Non-significant

* Significant at the 5.0 per cent level

** Significant at the 1.0 per cent level

*** Significant at the 0.1 per cent level 
yses of variance

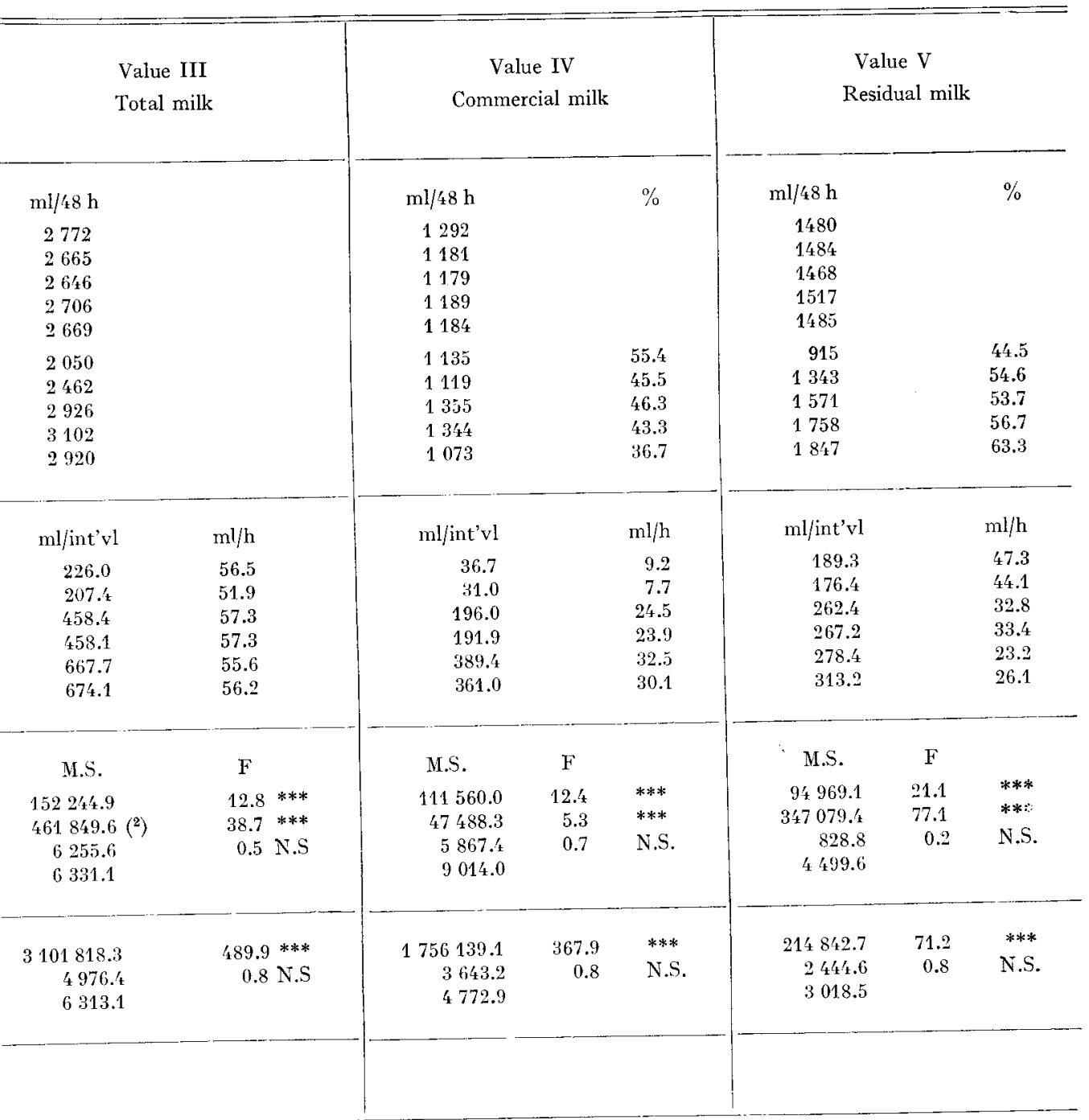

$\mathrm{g}$ this as a percentage of total residual milk. total residual milk.

( $\left.{ }^{2}\right)$ M.S. for periods can be further divided for linear and quadratic effects.

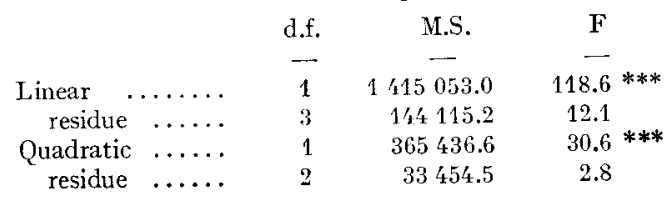


The treatment injections were of an oxytocin extract P.O.P. (purified oxytocic principle) produced by Armour Pharmaceuticals Co. Ltd (1). The required treatment concentrations were especially prepared in $2 \mathrm{ml}$. aliquots by the manufacturer. All oxytocin injections were flushed through the cannulae with $2 \mathrm{ml}$ of physiological saline. Stringent antiseptic measures were taken with the cannulae and syringes throughout the trial.

The ewes were housed on slats with a run out to a small covered yard adjacent to the milking parlour. The living area was brightly illuminated, day and night, throughout the experiment. The ewes were offered water, grass nuts and medium quality hay ad libitum and $\mathrm{I} \mathrm{kg}$ of concentrates at each of the three daily milkings $\left(^{2}\right)$.

The experiment was carried out at Lane Fnd Farm of the University of Reading from June 2oth to June $30 t h$, 1964 .

\section{RESULTS AND DISCUSSION}

Five ewes were unable to complete the experiment. There were three cases of illness and two cases in which the white cannulae became blocked. The data of the five ewes were discarded and the remaining results were analyzed by adjusting the following linear model : (see tables I and 2 for details of discarded ewes).

$$
y_{i j k l}=\mu+\mathrm{S}_{i}+\mathrm{P}_{j}+\mathrm{T}_{k}+\mathrm{E}_{i j k}+\mathrm{M}_{l}+\mathrm{D}_{k l}+\mathrm{E}_{i j k l}
$$

when $\mu=$ mean yield of a sheep in an interval

$\mathrm{S}:=$ effect due to $i$ th sheep $i=\mathrm{I}, 2, \ldots \ldots \ldots \ldots$

$\mathrm{P}_{j}=$ effect due to $j$ th period $j=\mathrm{I}, 2, \ldots \ldots \ldots \ldots, 5$

$\mathrm{T}_{k}=$ effect due to $k t h$ oxytocin treatment $k=\mathrm{I}, 2, \ldots 5$

$\mathrm{M}_{l}=$ effect due to $l$ th milking interval $l=\mathrm{I}, 2, \ldots \ldots 6$

$\mathrm{D}_{k l}=$ effect due to $l t h$ milking interval in combination with the $k t h$ oxytocin treatment.

The treatment means and the analyses of variance are given in table 3 .

No sign of illness or fall in appetite were observed in the remaining I 5 ewes.

\section{Galactokinetic responses}

The mean of R.M.I as a percentage of total residual milk (value I in table 3 ) clearly shows that increase of the dose above 5 i.u. does not enhance the removal of residual milk. 2,5 i.u., however, was shown to eject significantly less milk ( $P=0.05)$ The response to the saline treatment is surprisingly high. In view of this, we have attempted a post-experimental check on our routine. We milked eight ewes who had been machine milked and hand stripped some 5 minutes previously, and whose cannulae were handled as before, but who had received no saline injection. We were unable to obtain more than a few $\mathrm{ml}$ of milk. Inspection of the period means for the control treatment, 3 I.8, 22.5, 36. I, 30.4 and 43.2 p. Ioo respectively (these values are based on different groups of ewes in each case), showed no linear increase

(1) Purified oxytocic principle (P.O.P.) is obtained from whole pig pituitaries by a process involving the solvent fractionation of the anterior pituitary principle, followed by low temperature concentration of the remaining extract. The aqueous residue, thus obtained, is then extracted with organic solvents followed by weak acid aqueous extraction of the organic phase. $0,5 \mathrm{p}$. Ioo chlorbutol is added as a preservative. The principle is then diluted to the required strength.

The vasopressin content in this batch was $\mathrm{I}$ i. u. of vasopressin to $98 \mathrm{i}$. u. of oxytocin. Contamination with pituitary solutions other than vasopressin was not measurable.

$$
\begin{aligned}
& \text { Soya } \ldots \ldots \ldots \ldots \ldots \ldots \ldots \ldots \text { 20 p. } 100 \\
& \text { Fish meal.............. } 20 \text { \%. } 100 \\
& \text { Rolled barley................ } 60 \text { p. I00 } \\
& \text { Bone flour ................ } 5 \mathrm{~kg} \\
& \left.A+D_{3} \text { vitamin premix..... } 3 \mathrm{~kg}\right\} \text { per ton }
\end{aligned}
$$


with time, thus eliminating any possible explanation in terms of the ewes becoming accustomed to oxytocin removal of residual milk. ANDERSSON (I95I), Holiand et al. (I959), and ANDREOLI and CHIAUDANO (I96r), have described milk ejection in goat, in rabbit, and in woman respectively, in response to hypertonic saline solutions. Evidence of diuretic activity stimulated by hypertonic solutions has been reported by Gilman and Goodman (I937), Hare et al. (I943), Chambers et al. (I945) and VERNEY (I947). VERNEY also suggested that the elicitation of pituitary secretions by hypertonic solutions, is via hypothalmic osmoreceptors, but this hypothesis can hardly be applied to isotonic solutions! Nevertheless, the present data would seem to indicate a clear and active involvement of $i$ sotonic salt solutions with lactation processes, for which we can presently advance no explanation. A series of studies in which a range of saline concentrations are examined for quantitative ejection efficiency would be a first step in further investigation.

The importance of a double injection-milking routine is indicated by value II in table 3 . Within the range of $(5+5)$ i.u. to $($ Io +5$)$ i.u. there is no difference in effectiveness of udder evacuation. This is emphasised by the fact that even $(0+5)$ i.u. ejected 85 p. Ioo of the total residual milk. For the purposes of these calculations we have assumed that no residuum remains after the third injection. The mean quantities of R.M.2 and R.M.3, calculated from the oxytocin treatments only, expressed as percentage of total residual milk, were 7.0 and 3.7 p. Ioo respectively. In a further post-experimental investigation, we attempted to obtain a quantity of milk comparable to R.M.3 after a "dummy " third injection, but were unsuccessful. Whilst at this stage no physiological explanation for the importance of splitting the dose can be advanced, the practical importance for future experimental techniques is clear.

The doses used in the present experiment are much higher than most of those used by DeNAmur and MARTINET (I96r). In view of this and the fact that they used a single injection only, it is suggested that the relatively low percentage of residual milk they obtained may be a result of incomplete udder evacuation.

\section{Galactopoeitic effects and the inhibition of milk ejection}

The increase in total milk throughout the the experiment is clearly shown in figure $I$ and value III in table 3 . The period means (value III) are described by a highly significant quadratic term (see foot-note Table 3). Routine oxytocin removal of residual milk is thus shown to have an immediate and powerful galactopoeitic effect. The build up to a maximum increase of over 30 p. Ioo took 6-8 days. This clear example of galactopoeisis is in accordance with the suggestion made by BENSON and FOLIEY (I956) the results of DENAMUR (I953) and DENAMUR and MARTINET (I96I). Our own unpublished data have also shown a similar stimulatory effect, which was accompanied by an improved persistency in response to regular milkings with oxytocin. With the present design we are unable to discern whether the galactopoeisis is a result of residual milk removal (i.e. of more complete milking) or of some central hormonal or physiological effect "triggered " by exogenous oxytocin, or indeed by some combination of these factors. The total milk yields, so greatly affected by the experimental procedure as a whole, are not affected at all by the treatments. In quantitative terms no difference in total milk secretion could be demonstrated 
within a range of 30 i.1. (treatment C) to 60 i.u. (treatment E) of oxytocin intake per day. AzImov's suggestion that oxytocin is an agent concerned with mammary resorption (AzIMov, 1959, and Azimov et al., I962) does not find support within this relatively high but differentiated dose range of oxytocin administrations.

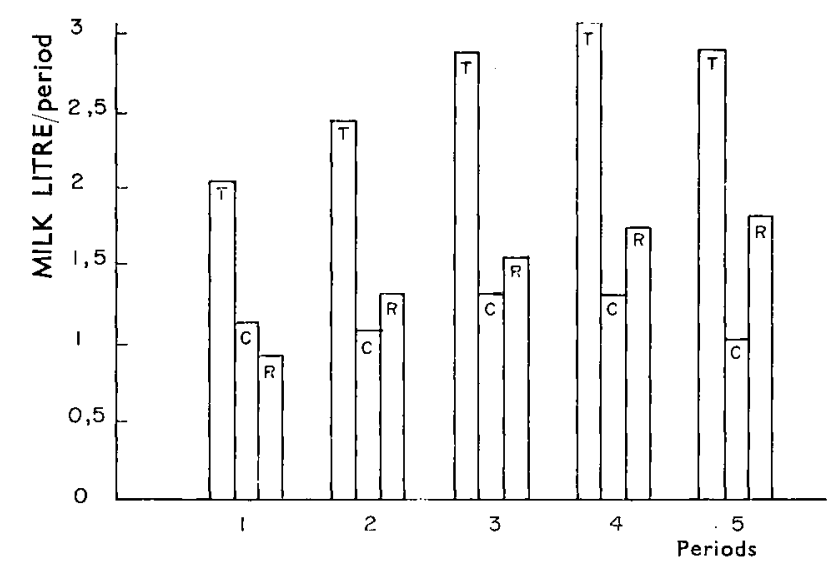

FIG. I. - Anount of Tolal $(T)$, Commercial $(C)$ and Residual $(R)$ milks in the five consecutive two days periods of the latin square (in 4 th month of lactation)

Quanitié de lail total $(T)$, commercial $(C)$ et résiduel $(R)$ au cours des cinq périodes conséculives de deux jours (au cours du $4^{e}$ mois de lactation)

Denamur and MarTinet (I965) have shown that ewes, in which 5 i.u. were administered at every milking throughout lactation to remove residual milk, produced significantly less total milk than ewes in which $0 . I, 0.5$ and $x$ i.u. were given. All four groups produced significantly more milk than the control ewes milked as in commercial practice (no oxytocin). They propose, on the basis of these results, that high dosage may depress yield. In view of our experimental design the present data cannot be used to test this hypothesis except to say that when doses of 30-60 i.u. per day were used for residual milk removal, a uniform 30 p. Ioo galactopoeitic effect was observed.

Another interesting feature shown by the period means (values IV and $\mathrm{V}$ in table 3 ) is the effect of time on the change in relative importance of the commercial and residual fractions. In order to eliminate the bias due to the period effect on total milk (see above) the absolute values have been transformed into percentages. These observations are in accord with results reported in cow studies (SHAw, I942 and DoDD, 1964). The very large increase with time in residual milk percentage, as shown by the period means, would suggest that the introduction of the experimental procedure (the painless administration of oxytocin after normal milking and the subsequent removal of residual) has a serious inhibitory effect on milk ejection in response to normal milking stimuli.

Denamur and Martinet (I965) present pertinent data on this subject. They compared the percentage of residual milk over the whole lactation in ewes when residual milk was removed with the aid of oxytocin doses from o.I to 5 i.u. The percentage of residual milk was shown to increase with dose. They interpret this 
to show that high doses of exogenous oxytocin inhibit the ejection of the commercial fraction. By comparison with their doses, the present levels are very high and might well be expected to have inhibited ejection so dramatically. In view of the general acceptance of the unconscious nature of the milk ejection, we are unable to offer any physiological explanation for this general phenomenon.

The galactopoeitic effect and inhibition of ejection described above have important practical implications for further experimentation. It is thus recommended that secretion rate and milk ejection experiments in ewes, involving the oxytocin removal of residual milk are preceded by at least 8 days of treatment discard period.

\section{Intervals, preceding intervals and interaction with oxytocin level}

The secretion rate of total milk is shown to be unaffected by the interval length, or indeed by the preceding interval (see sub-plots of value III in table 3). The relatively low secretion rate in the 4 hours interval following 12 hours appears to be an individual aberrant, since the deviations from the regression of total milk on time are without significance. The constancy of the secretion rates over the range of interval lengths is in accordance with the reports of ScHMrDT (I960) and Tucker et al. (I96I), who showed that the secretion rate of milk in cows was unaffected by time for up to I2 hours after milking. The interaction terms between interval and oxytocin treatment were non-significant for all examined values. Inspection of the sub-plots of the percentage of residual milk yielded in response to the treatment injection (value I) shows a slight tendency for milk ejection to become more efficient with the lengthening of the interval. (the figure for Value I, 75 p. Ioo approximately, is, of course, a low one because of the weighting given by the control treatment.) The combined effect of injections I and II (value II) shows no such tendency. It is, therefore, concluded that udder evacuation can be carried out after varying milking intervals of up to I2 hours without any special adaptation of technique or differentiation in level of oxytocin dose.

Reçu pour publication en juin 1966.

\section{ACKNOWLEDGEMFNTS}

This project was financed by an award from the MirinM SACHer Charitable Trust and it was carried out whilst the senior author was in receipt of the HUNTLEY and PALMER research studentship. The oxytocin was kindly supplied by Mr W. F. TICrHurst of ARMours Pharmaceutical Co. Ltd. Our thanks are gratefully recorded to all concerned. For additional help, thanks are due to $\mathrm{Mr}$ M. Paran, Iately Agricultural Counsellor at the Embassy of Israel, London, to Dr D. RobertsonSMITH and the staff of the Pathology Laboratory at the Royal Berkshire IIospital, to Dr J. K. Brookhouse and Miss F. J. NuTt of the Department of Applied Statistics, University of Reading, to Dr G. KNaGgs of the National Institute for Research in Dairying and to Miss E. BROADBENT for technical assistance.

\section{SUMMARY}

I. Oxytocin doses ranging from 2.5 - $10 \mathrm{i}$. u. were tested for effectiveness in the ejection of residual milk in 15 ewes over three milking intervals $(4,8$, and 12 hours). The assay was carried out using a Latin square split-plot design. 
2. Effective ejection was obtained from two injections of 5 i.u. each. The administration of a second injection was shown to be important. Dose efficiency was independant of interval length and quantity of residual milk.

3. A weak ejection was elicited by the administration of physiological saline.

4. Regular oxytocin removal of residual milk had a powerful galactopoeitic effect on milk secretion and appeared to have a strong inhibitory effect on normal milk ejection.

5. The secretion rate of milk was shown to be a constant and to be unaffected by preceding intervals over the tested range.

\section{RÉFÉRENCES BIBLIOGRAPHIQUES}

Anderssor B., I95I. Some observations on the neuro-hormonal regulation of milk ejection. Acta. physiol. scand., 23, 1-7.

Andreolt C., Chiaundo G., rg6i. Milk-ejecting effect of hypertonic saline solution in woman. Gynaecologia, 151, 461-64.

Azimov G.-I., I959. Some processes accompanying the secretion of milk. XV Int. Dairy Congr., I3-9.

Azimov G.-I., Orlov A.-F., Bejugina O.-P., I962. Milk secretion and re-absorption from the udder. Nature, 193, 985-986.

Benson G.-K., Folley S.-J., I956. Oxytocin as stimulator for the release of prolactin from anterior pituitary. Nature, 197, 700 .

Chambers G.-H., Melville F.-V., IIare R.-S., Hare K., 1945. Regulation of the release of pituition by changes in the osmotic pressure of the plasma. Am. J. Physiol, 144, 31 1-320.

Denamur R., 1953. Action de doses répétées d'ocytocine sur la sécrétion du lait chez la chèvre. $C$. $R$. Soc. Biol., 147, 88-92.

Denamur R., Martinet J., i961. Action de l'ocytocine sur la sécrétion du lait de brebis. Ann. Endocr., 22, $777-78 \mathrm{r}$.

Denamur R., Martinet J., 1965. Personal communication.

DoDd F.-HI., i 964 . Personal communication.

ELLIOTT G.-M., I959. The effect of milk accumulation in the udder of the dairy cow upon secretion rate it; bearing on certata milking practices. Ph. D. Thesis. Univ. Reading.

Eyal F., ig6r. Personal communication.

Gilman A., Goommay L., 1937. The secretory response of the posterior pituitary to the need for water conservation. J. Physiol, 90. I I $3^{-124}$.

Ilare. R.-S., HARE K., Pinllips D.-M., I943. The renal excretion of chloride by the normal an .. by the diabetes insipidus dog. Am. J. Physiol., 140, 334-348.

Holland R.-C., Cross B.-A., SAWyer G.-H., r959. Effects of intracarotid injections of hypertonic solutions on the neurohypophyseal milk-cjection mechanism. Am. J. Physiol., 196, 791-795.

Ingerslev M., Pinholt K., r962. Oxytocin treatment during establishment of lactation. Acta obstel. gynec. scand., 41, I 59-I68.

Kosin J.-II., Petersey W.-F., 1955. Complementary milk and its relationship to lactation. J. Dairy Sci, 38, $788-796$.

MCCANCE I., I959. The determination of milk yield in the Merino ewe. Aust. J. agric. Res., 10, $839-853$.

OTT 1., ScotT J.-C., igio. The action of infundibulin upon mammary secretion. Proc. Soc. exper. Biol. Med., 8, 48-49.

Scimidt G.-H., i960. Effect of milking intervals on the rate of milk and fat secretion. J. Dairy Sci., 43, 213 -220.

SEMJAN S., ig62. Residual milk of sheep. XVI Int. Dairy Congr., 1, 17-24.

Samjan S., ig6.4. Personal communication.

SHaw J.-C., I942. The effect of oxytocin on milk and milk fat secretion. J. Dairy Sci., 25, 105 I-1055.

Tucker H.-A., ReEce R.-P., MAther R.-E., I961. Udder capacity estimates as effected by rate of milk secretion and intermammary pressure. J. Dairy Sci., 44, i $725^{-1} 73^{2}$.

VERnEY E.-B., 1948. The antidiuretic hormone and the factors which determine its release. Proc. R. Soc. $B, 135,25$-I06.

Williams (j.-J., 1949. Iixperimental designs balanced for the estimation of residual effects of treatments. Aust. J. Sci.. Res., A., 2, 149-168. 